The Final Report of the National Waterways Commission

Author(s): Robert M. Brown

Source: Annals of the Association of American Geographers, Vol. 3 (1913), pp. 88-92

Published by: Taylor \& Francis, Ltd. on behalf of the Association of American Geographers

Stable URL: http://www.jstor.org/stable/2560692

Accessed: 27-06-2016 06:48 UTC

Your use of the JSTOR archive indicates your acceptance of the Terms \& Conditions of Use, available at

http://about.jstor.org/terms

JSTOR is a not-for-profit service that helps scholars, researchers, and students discover, use, and build upon a wide range of content in a trusted digital archive. We use information technology and tools to increase productivity and facilitate new forms of scholarship. For more information about JSTOR, please contact support@jstor.org.

Association of American Geographers, Taylor \& Francis, Ltd. are collaborating with JSTOR to digitize, preserve and extend access to Annals of the Association of American Geographers 


\title{
THE FINAL REPORT OF THE NATIONAL WATERWAYS COMMISSION*
}

\author{
ROBERT M. BROWN
}

CONTENTS

Character of the Report............................ 88

Desired Depth of Water............................ 89

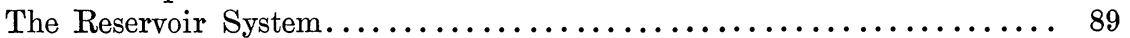

Influence of Forestation upon Navigation and Floods.............. 90

The Railway Control................................. 91

New Canals Proposed.............................. 92

Character of the Report.-The final report of the National Waterways Commission is one of the most important documents on our waterways that has been issued. There is no doubt that the solution of our transportation problems, in so far at least as the water courses are concerned, has been delayed by stubbornness on the part of individuals and associations in making their special hobbies the pivotal matter of the situation. To some degree the question has become a controversy and this has assumed too much the aspect of a political campaign with vociferations, platforms and slogans. Such a state of affairs is deplorable because the very complexity of the task of inland waterways ought to summon the leaders in this field of endeavor to a broad policy of consideration for every project that has a degree of plausibility. There will be differences of opinions and inevitably widely different remedies will be offered, but these differences are not going to be settled by forensic display. So it is refreshing to read a report where due weight is given to every intelligent opinion and where the discussion is apparently without bias. The two main issues which have distressed waterway conventions are the desired depth of water to be attained in the Mississippi River, the main artery of the

*The Final Report of the National Waterways Commission. Senate Document No. 469, 62d Congress, $2 \mathrm{~d}$ Session. Final Report of 62 pages. 9 appendices, with a total of 579 pages.

Government Printing Office, Washington, 1912.

The National Waterways Commission was created by Act of Congress of March 3, 1909. The Commission consisted of twelve members of the Senate and House of Representatives with Theodore H. Burton as Chairman. The duty imposed upon the Commission by the Act was to investigate questions relating to water transportation and the improvement of waterways. The preliminary report was submitted to Congress in January, 1910, and the final report in March, 1912. 
central portion of the country, and the practicability of reservoirs in preventing floods and in maintaining a low-water navigable channel.

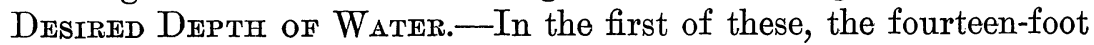
and the Lakes-to-the-Gulf advocates have been opposed to the nine-foot waterway plan of the Mississippi River Commission. The final report of the National Waterways Commission does not admit the question as one of vital importance, and the only discussion of depth is found in the Preliminary Report of this same Commission, printed as Appendix I of the Final Report, in which two points are presented: first, canals for deep draft vessels are profitable only when these canals connect navigable waters located near each other as the Welland Canal; or when a comparatively short canal will save a great sailing distance as the Panama Canal, or when a large city is situated within easy distance of the coast as in the case of Manchester, England: and, second, the weight of evidence favors, in general, open river navigation to a lock and dam or canalized navigation on the ground of economy. At the same time, it is recognized that if a growth of traffic should eventually be realized, thorough regularization or canalization may be a just demand.

The Reservoir Srstem.-The second point of controversy centers about the reservoir system of flood prevention and low water control. The Report considers this method of stream regulation at some length. The point is clearly made that a reservoir system built primarily for flood prevention will not be practicable as a means of aiding navigation or power development. If it is desired to use the reservoirs for all three functions, it will be necessary to have the reservoir large enough to impound the requisite sum volume of water demanded by each project if acting separately. There is cited the case of the proposed reservoir on the Genesee River. This contract provides for a dam 152 feet high and the volume of water is figured sufficient for all purposes in the scheme of the promoters. The first 32 feet of water are to be held for infrequent use, the next 45 feet of water are intended to raise the water stage during the low water season, the next 55 feet are for power development and of the remaining 20 feet, 15 are planned to lower the flood level and 5 are held in reserve for extreme floods. At the end of the flood season, this top water will be drained off to the level of the water for power development, 132 feet. Such a policy if applied to the Mississippi would probably mean a cost too great in comparison to the protection it would insure. It is a reasonable position to take that the reservoirs on the Ohio River which are proposed for the improvement of navigation cannot be of service, except incidentally, for flood protection and power development, and the theory so persistently advanced that the reservoir system which will give adequate security from overflow of levees will pay their way through the 
sale of power cannot longer be reasonably entertained. The conclusions of the Commission on this point are stated carefully, although they leave the question still unsettled. This is a wise policy as much of the answer must be based on experimentation, and this state and municipal governments are beginning to undertake. They do not unreservedly recommend reservoirs, but they do look in the direction of this method of control in the proper time. Their creed is somewhat as follows:

1. The necessity of controlling floods increases with the development of the country. This is not new nor profound, but it is a basal fact in the reservoir scheme because the interest of the cost of the plant must be met by the profits of the protected areas.

2. The using of storage reservoirs becomes more practicable where the value liable to damage is great. This is a paraphrase of the first. The Commission adds that this condition has been attained on some streams.

3. This conclusion states that the Commission does not know on what streams the construction of reservoirs would result in benefits commensurate with the cost.

4. The Federal Government has no constitutional authority to engage in works intended primarily for flood prevention or power development. In this statement there seems to be implied that reservoirs can be built to aid navigation only. Thus in the case of the Genesee River dam of 152 feet, under the charge of the water supply Commission of New York State, the 55 feet for power development would have to be eliminated if it was a Federal contract reducing the height to 97 feet and possibly the 20 foot for flood catchment which would make a still further reduction to 77 feet, or about one-half the proposed height.

Two more conclusions which point out the lines of future investigation are listed. It will be seen that while the Commission appear to be perfectly satisfied concerning the practicability of reservoirs in stream regulation, they hesitate to say that the time is ripe for the building of them on any particular stream. Yet notwithstanding the uncertainty of mind which is stamped on the formal conclusions of the Commission, the entire discussion of the reservoir system is valuable and a contribution.

Influence of Forestation upon Navigation and Floods.-Another subject covered in this Report is the influence of forestation upon navigation and flood prevention, concerning which there are many conflicting opinions in print. In this as in the other lines, the Commission have given an impartial review of the discussion and have reached certain conclusions which, as one might expect, are much more moderate 
than the views of the leaders of the controversy over forest influences. No universal law of influence of forests upon precipitation, run-off and erosion is found. The variations of rainfall, slope and porosity of the soil are such that on one stream the effects of forests may be beneficial to stream flow and mitigate floods, while on another the opposite results may be experienced. Moreover, the Commission is convinced that in no case can forests be relied upon to prevent floods or low water conditions, nor will they take the place of storage reservoirs in securing a uniform stream flow. The main benefit of the forest cover lies in the prevention of erosion; and, inasmuch as this conclusion has been reached, there seems to be no reason why forests at headwaters of streams should not be removed if the land is desirable for agriculture providing a proper vegetation cover is given the land or some suitable manipulation of land slopes is undertaken in order to prevent erosion.

The Railway Control.- The depth of the Mississippi waterway and the reservoir system of control are subjects which have stirred deeply the believers in inland water routes; the effects of deforestation on stream flow is a question that has been discussed, somewhat bitterly I fear, as a concomitant but not as a main issue, but the lack of co-operation between the railways and the waterways is after all the sore spot in our waterway troubles. In two directions, the railroads have blocked the increased use of waterways; first, by the control of water terminals, and, second, by their refusal to co-operate by prorating or otherwise in water shipments. The Commission believes that the proper solution of the terminal question is most vital to the future of water transportation. The railroads own or control a large proportion of the water fronts which are held in a manner adverse to water traffic either by demands for unreasonable terminal charges or by preventing the development of water frontage. For the solution of the problem, the Commission proposes that the state or municipal officials condemn such property for public use. The cooperation of railway and waterway is a more difficult task because there are so many ways open by which, within the letter of the law, a railway company may stifle the intent of the law. There is nothing ethically wrong in lowering rates in competition providing these rates are neither discriminating nor temporary. The shipper or the buyer is interested in waterways only as they reduce the marketable cost of his wares, and consequently he enjoys competition rather than harmony. The tendency of large railroads to combine and the control of railways over waterways are, to be sure, a move towards harmony and co-operation but the elimination of competition establishes a monopoly in a branch of the public service which renders them a subject of control by the Federal Government. The Commission recommends that waterways be under the control of the Interstate 
Commerce Commission and be made common carriers-a move which would allow the Commission to establish a connection between rail and water lines by requiring joint rates.

New Canals Proposed.-In addition to the subjects discussed in this review, the United States National Waterways Commission advises the construction of the proposed canal between Lake Erie and the Ohio River near Pittsburgh, and pronounces entirely feasible both the Lake Erie-Lake Michigan artificial waterway and the AnacostiaChesapeake canal.

The larger discussions of a number of the topics by experts are collected as appendices. Here may be found valuable papers on storage reservoirs by Leighton, Follansbee and Bixby, on forest influences with an extensive bibliography by Zon, on legal aspects by Mooney and on a comparison of American and European waterways by Merchant. Altogether the volume of 580 pages contains a vast fund of information and the pages devoted to the Final Report proper offer a safe and valuable basis on which to found any study of the waterway problem. 